\title{
Attitude of Students towards Rural Agriculture Work Experience Programme in Rajasthan State, India
}

\author{
Kailash Chand Jakhar ${ }^{1}$, Madhuri Joshi ${ }^{1}$, Bajaranglal Choudhary ${ }^{2 *}$ and Sunil Kumar $^{1}$ \\ ${ }^{1}$ Department of Extension Education, S.K.N. Agriculture, Jobner (Jaipur), India \\ ${ }^{2}$ Department of Animal Husbandry and Dairy, IAS, BHU, Varanasi, India \\ ${ }^{3}$ Department of Agronomy, IAS, BHU, Varanasi, India \\ *Corresponding author
}

\section{A B S T R A C T}

Agricultural education is an important tool in ensuring increased agricultural productivity, sustainability, environmental and ecological security, profitability, job security and equity. Different committees (ICAR Review Committee 1979; Deans Committee 1981) recommended for strong linkage of agricultural education with actual farming situation through the programme. Considering the importance of agricultural knowledge on socio-economic behaviour of the farmers, Agricultural Graduates during internship have to work and study in rural areas as per university norms it is a course offered by SAUs normally in the final year (VII or VIII semester) of undergraduate degree programme. In 12th plan, Rural Agriculture Work Experience (RAWE) Programme has been reconstructed and proposed as 'Rural Entrepreneurship and Awareness Development Yojana' (READY). The programme aims at entrepreneurship development among the youth. The present study was conducted in the State Agriculture Universities of Rajasthan. There were 5 SAUs namely, SKRAU Bikaner and MPUAT Udaipur, SKNAU Jobner, AU Kota and AU Jodhpur. Out of the 5 universities 3 universities were having UG and PG degree programmes. So these universities have been selected for the study. There are 3 Agriculture colleges Viz. S.K.N. College of Agriculture, Jobner (SKNAU, Jobner), Rajasthan college of Agriculture, Udaipur (MPUAT, Udaipur) and college of Agriculture, Bikaner (SKRAU, Bikaner) where the PG degree in agriculture is offered and RAWE programme is being conducted for last 10 years. Hence only these three colleges have been selected for the study. 30 students from each college selected randomly. Thus the sample was comprised of 90 students. There were 74 students given attitude about educational tour because, 16 students from total 90 were taken their UG degree from RCA, Udaipur and there was no education tour conducted. The results obtained might be due to facts that farmers allotted to the students in the particular area of KVK were very cooperative and told about the cultural background of that area to students, which might have helped in convincing students about village attachment, which has resulted in changing the attitude of students towards village attachment in RAWE programme. RAWE programme was seriously implemented by the state agricultural universities and gave more attention on communication, technical skill and managerial skills respectively. Teachers were also very skilled in a particular area of skill training, which has resulted in changing the attitude of students towards skill training in RAWE programme. Educational tour is very important activity in SAUs which is helpful in exposure of the students with new institutions and technologies. Students were so cooperative in educational tour and spots visited very well under the guidance of good staff. This has resulted in to increased favourable attitude towards educational tour of RAWE programme. 


\section{Introduction}

Agricultural education is an important tool in ensuring increased agricultural productivity, sustainability, environmental and ecological security, profitability, job security and equity. Different committees (ICAR Review Committee 1979; Deans Committee 1981) recommended for strong linkage of agricultural education with actual farming situation through the programme [1]. Considering the importance of agricultural knowledge on socio-economic behaviour of the farmers, Agricultural Graduates during internship have to work and study in rural areas as per university norms. In India, Randhawa Committee (1992) recommended the Rural Agriculture Work Experience (RAWE) Programme for imparting quality, practical oriented education for the agriculture degree programme. It is a course offered by SAUs normally in the final year (VII or VIII semester) of undergraduate degree programme. In 12th plan, Rural Agriculture Work Experience (RAWE) Programme has been reconstructed and proposed as 'Rural Entrepreneurship and Awareness Development Yojana' (READY). The programme aims at entrepreneurship development among the youth.

\section{Materials and Methods}

The present study was conducted in the State Agriculture Universities of Rajasthan. there were 5 SAUs namely, SKRAU Bikaner and MPUAT Udaipur, SKNAU Jobner, AU Kota and AU Jodhpur. Out of the 5 universities 3 universities were having UG and PG degree programmes. So these universities have been selected for the study.There are 3 Agriculture colleges Viz. S.K.N. College of Agriculture, Jobner (SKNAU, Jobner), Rajasthan college of Agriculture, Udaipur (MPUAT, Udaipur) and college of Agriculture, Bikaner (SKRAU, Bikaner) where the PG degree in agriculture is offered and RAWE programme is being conducted for last 10 years. Other colleges affiliated by the SAUs do not offer post graduate degree in Agriculture.Hense only these three colleges have been selected for the study. 30 students from each college selected randomly. Thus the sample was comprised of 90 students. There were 74 students given attitude about educational tour because, 16 students from total 90 were taken their UG degree from RCA, Udaipur and there was no education tour conducted.

The data were collected with the help of questionnaire consisting of measuring devices of variables along with face to face contact from the respondents. In formulating the questions and statements for the questionnaire, the investigator has taken opinion and guidance of the experts and other extension personnel. Collected data were tabulated and analyzed by using mean score, standard deviation, percentage and rank.

\section{Results and Discussion}

\section{Attitude of students towards village} attachment in RAWE programme

The data given in table no. 1 indicate that respondents possessed most favourable attitude on the statements like "RAWE has helped me to get familiar with rural life" which secured highest mean score (4.51 MS), hence this statement was ranked first. The second highest mean score (4.46 MS) secured by the statement "RAWE has helped me to increase in knowledge on crops / enterprises" which was ranked second followed by "RAWE has helped me to develop favourable attitude towards farming enterprise and the farmers" (4.11 MS), and "RAWE has helped me to learn experiences of rural setting" (3.88 MS) ranked third and fourth, respectively.

The results obtained might be due to facts that 
farmers allotted to the students in the particular area of KVK were very cooperative and told about the cultural background of that area to students, which might have helped in convincing students about village attachment, which has resulted in changing the attitude of students towards village attachment in RAWE programme.

The data given in the table also revealed that the students have moderate attitude towards other statements of village attachment in RAWE programme like "RAWE has helped me to gain practical experiences" (3.78 MS), "RAWE has helped me to understand farmers problems" (3.64 MS), "RAWE has helped me to gaining knowledge on time utilization pattern of rural people" (3.62 MS), "RAWE has helped me to provide opportunity to meet role models in agriculture" (3.47 MS), "RAWE has helped me to understand farming systems prevailing in the village" (3.43 MS), "RAWE has not helped me to getting Knowledge on rural cultural background" (3.25 MS), "RAWE has not helped me to learn need assessment and programme Planning" (3.13 MS), "RAWE has not helped me to understand the sentiments of farmers" (3.12 MS), "RAWE has not helped me to developing right attitude towards farming community" (3.11 MS) and "RAWE has not helped me to know about the economic status of farmers" (2.95 MS). The reason is because staff of KVK and farmers took this programme very seriously for the students. Farmers were in regular touch with the KVK. It means programme provided to students about village attachment bring significant improvement in knowledge of students about rural area and agriculture.

The students expressed least favourable attitude towards statements of village attachment in RAWE programme like "RAWE has not helped me to exposed to rural livelihood security and survivility", "RAWE has not helped me to increase in yield of crops / enterprises", "RAWE is not helpful for exposure with social system and institutions", "RAWE has not helped me to reduce cost of cultivation" owing to the mean score $2.87,2.85,2.76$ and 2.67 respectively.

This might be due to the facts that most of students have favourable attitude towards village attachment and faced less constraints in doing agricultural practices as they belong to rural areas. Further the duration of village attachment in RAWE programme is less, so students are not able to understand total practices to reduce cost of cultivation. The findings of this study support the findings of $[2,3$,$] .$

\section{Attitude of students towards skill training in RAWE programme}

The data given in table no. 2 indicate that respondents possessed most favourable attitude regarding "RAWE has helped me to improve my skills in the related area" which secured highest mean score (3.90 MS), hence this statement was ranked first. The second highest mean score (3.80 MS) secured by the statement "RAWE has helped me to improve my communication skills" which was ranked second followed by "RAWE has helped me to improve the technical skill in performing various agricultural operations" (3.73 MS), and "RAWE has helped me to improve managerial skills" (3.64 MS) ranked third and fourth, respectively.

The results so found might be due to facts that skill training programme of RAWE programme was seriously implemented by the state agricultural universities and gave more attention on communication, technical skill and managerial skills respectively. Teachers were also very skilled in a particular area of skill training, which has resulted in changing the attitude of students towards skill training in RAWE programme. 
Table.1 Statement wise attitude of students towards village attachment

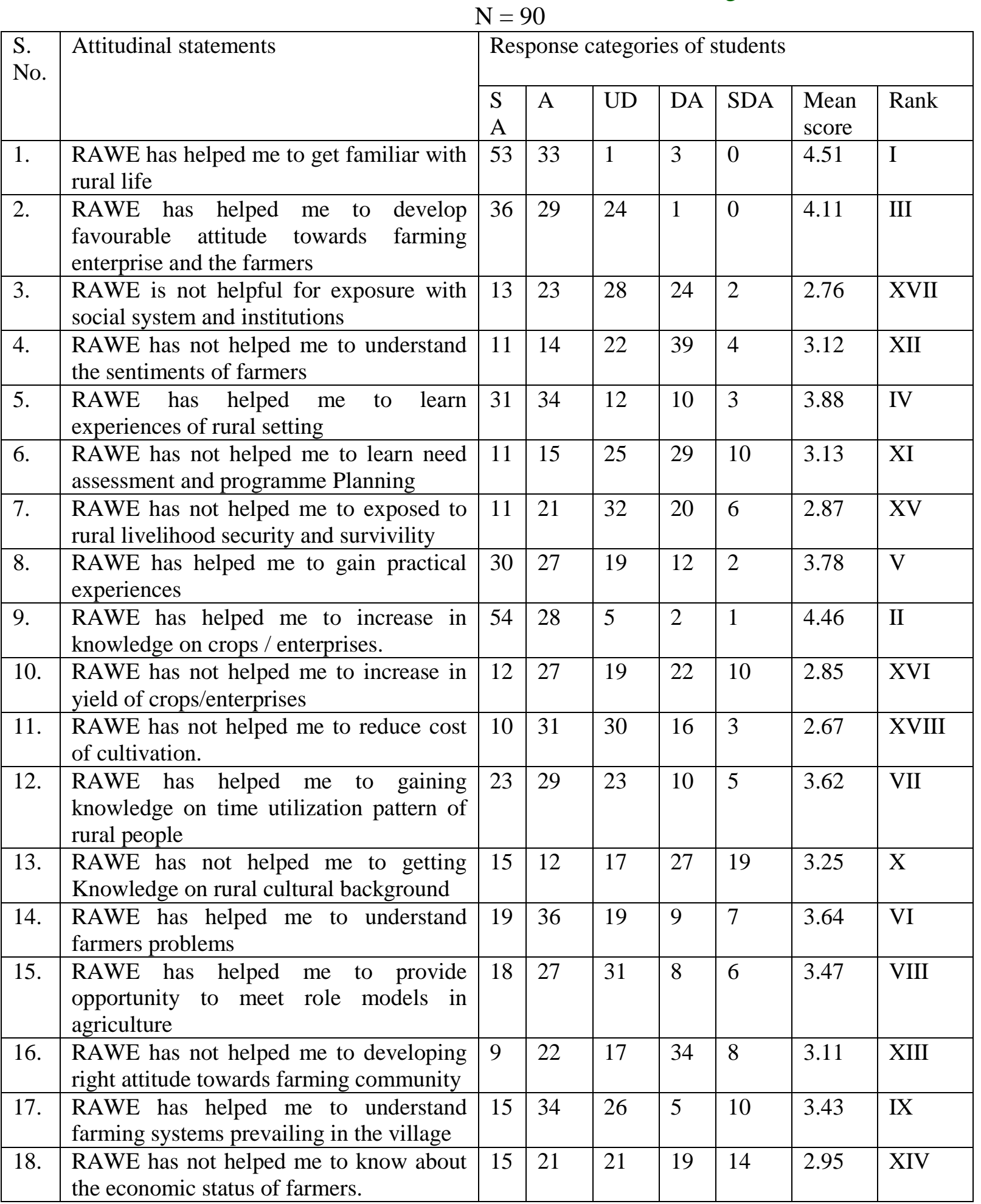

SA: Strongly agreed a: Agreed UD: Undecided DA: Disagree SDA: Strongly Disagree 
Table.2 Statement wise attitude of students towards skill training

\begin{tabular}{|c|c|c|c|c|c|c|c|c|}
\hline \multirow{3}{*}{$\begin{array}{l}\text { S. } \\
\text { No. }\end{array}$} & \multirow{3}{*}{ Attitudinal statements } & & & & & & \multicolumn{2}{|c|}{$\mathrm{N}=90$} \\
\hline & & \multicolumn{5}{|c|}{$\begin{array}{l}\text { Response categories } \\
\text { of students }\end{array}$} & \multirow{2}{*}{\begin{tabular}{|l}
$\mathrm{Me}$ \\
an \\
scor \\
$\mathrm{e}$
\end{tabular}} & \multirow[t]{2}{*}{$\begin{array}{l}\text { Ran } \\
\mathrm{k}\end{array}$} \\
\hline & & $\mathrm{S}$ & A & $\begin{array}{l}\mathrm{U} \\
\mathrm{D}\end{array}$ & $\begin{array}{l}\mathrm{D} \\
\mathrm{A}\end{array}$ & $\begin{array}{l}\text { SD } \\
\text { A }\end{array}$ & & \\
\hline 1. & $\begin{array}{l}\text { RAWE has helped me to improve my skills in } \\
\text { the related area }\end{array}$ & $\begin{array}{l}3 \\
1\end{array}$ & $\begin{array}{l}3 \\
0\end{array}$ & $\begin{array}{l}2 \\
0\end{array}$ & 7 & 2 & $\begin{array}{l}3.9 \\
0\end{array}$ & I \\
\hline 2. & $\begin{array}{l}\text { RAWE has helped me to improve my } \\
\text { communication skills }\end{array}$ & $\begin{array}{l}2 \\
5\end{array}$ & $\begin{array}{l}3 \\
4\end{array}$ & $\begin{array}{l}1 \\
9\end{array}$ & 9 & 3 & $\begin{array}{l}3.8 \\
0\end{array}$ & II \\
\hline 3. & $\begin{array}{l}\text { RAWE has not helped me to develop leadership } \\
\text { quality }\end{array}$ & $\begin{array}{l}1 \\
5\end{array}$ & $\begin{array}{l}1 \\
1\end{array}$ & $\begin{array}{l}1 \\
7\end{array}$ & $\begin{array}{l}2 \\
6\end{array}$ & 21 & $\begin{array}{l}3.3 \\
0\end{array}$ & VI \\
\hline 4. & $\begin{array}{l}\text { RAWE has developed capacity in me to start an } \\
\text { enterprise }\end{array}$ & $\begin{array}{l}1 \\
5\end{array}$ & $\begin{array}{l}3 \\
6\end{array}$ & $\begin{array}{l}2 \\
1\end{array}$ & $\begin{array}{l}1 \\
3\end{array}$ & 5 & $\begin{array}{l}3.4 \\
7\end{array}$ & $\mathrm{~V}$ \\
\hline 5. & $\begin{array}{l}\text { RAWE has helped me to improve managerial } \\
\text { skills }\end{array}$ & $\begin{array}{l}1 \\
6\end{array}$ & $\begin{array}{l}4 \\
2\end{array}$ & $\begin{array}{l}2 \\
1\end{array}$ & 6 & 5 & $\begin{array}{l}3.6 \\
4\end{array}$ & IV \\
\hline 6. & $\begin{array}{l}\text { RAWE has not helped me to develop favourable } \\
\text { attitude about the related enterprise }\end{array}$ & $\begin{array}{l}1 \\
5\end{array}$ & $\begin{array}{l}2 \\
3\end{array}$ & $\begin{array}{l}1 \\
9\end{array}$ & $\begin{array}{l}2 \\
6\end{array}$ & 7 & $\begin{array}{l}2.8 \\
5\end{array}$ & IX \\
\hline 7. & $\begin{array}{l}\text { RAWE has not helped me to develop ability of } \\
\text { cooperation and team work }\end{array}$ & $\begin{array}{l}1 \\
1\end{array}$ & $\begin{array}{l}1 \\
8\end{array}$ & $\begin{array}{l}2 \\
5\end{array}$ & $\begin{array}{l}2 \\
3\end{array}$ & 13 & $\begin{array}{l}3.1 \\
0\end{array}$ & VIII \\
\hline 8. & $\begin{array}{l}\text { RAWE has not helped me to develop confidence } \\
\text { and professional competence }\end{array}$ & $\begin{array}{l}1 \\
5\end{array}$ & $\begin{array}{l}1 \\
1\end{array}$ & $\begin{array}{l}2 \\
9\end{array}$ & $\begin{array}{l}1 \\
8\end{array}$ & 17 & $\begin{array}{l}3.1 \\
2\end{array}$ & VII \\
\hline 9. & $\begin{array}{l}\text { RAWE has helped me to improve the technical } \\
\text { skill in performing various agricultural } \\
\text { operations }\end{array}$ & $\begin{array}{l}2 \\
5\end{array}$ & $\begin{array}{l}3 \\
1\end{array}$ & $\begin{array}{l}1 \\
9\end{array}$ & $\begin{array}{l}1 \\
1\end{array}$ & 3 & $\begin{array}{l}3.7 \\
3\end{array}$ & III \\
\hline 10. & $\begin{array}{l}\text { RAWE has not helped me to improve the } \\
\text { marketing skill }\end{array}$ & $\begin{array}{l}1 \\
2\end{array}$ & $\begin{array}{l}3 \\
0\end{array}$ & $\begin{array}{l}1 \\
9\end{array}$ & $\begin{array}{l}1 \\
8\end{array}$ & 11 & $\begin{array}{l}2.8 \\
4\end{array}$ & $\mathrm{X}$ \\
\hline
\end{tabular}

SA: Strongly agreed $\quad$ a: Agreed UD: Undecided DA: DisagreeSDA: Strongly Disagree 
Table.3 Statement wise attitude of students towards educational tour

\begin{tabular}{|c|c|c|c|c|c|c|c|c|}
\hline & & & & & & & & $=74$ \\
\hline S. No. & Attitudinal statements & Resp & nse c & gories & stude & & Mean & Rank \\
\hline & & SA & $\mathrm{A}$ & UD & DA & SDA & score & \\
\hline 1. & $\begin{array}{l}\text { RAWE has helped me to know } \\
\text { about the climate, soil, cropping } \\
\text { system, land use pattern, } \\
\text { irrigation sources and fertilizer } \\
\text { status of different states. }\end{array}$ & 39 & 23 & 7 & 0 & 5 & 4.22 & II \\
\hline 2. & $\begin{array}{l}\text { RAWE has not helped me to } \\
\text { know about the livestock } \\
\text { positions of different states }\end{array}$ & 14 & 18 & 13 & 23 & 6 & 2.85 & XII \\
\hline 3. & $\begin{array}{l}\text { RAWE has helped me to know } \\
\text { about various technologies } \\
\text { developed by different } \\
\text { agricultural institutions of } \\
\text { different states }\end{array}$ & 4 & 6 & 20 & 20 & 24 & 3.72 & IV \\
\hline 4. & $\begin{array}{l}\text { RAWE has not helped me to } \\
\text { know about the objectives and } \\
\text { mandate of different agricultural } \\
\text { institutions and organisations }\end{array}$ & 11 & 14 & 17 & 18 & 14 & 3.18 & VII \\
\hline 5. & $\begin{array}{l}\text { RAWE has not helped me to } \\
\text { know about the working pattern } \\
\text { of different agricultural } \\
\text { institutions and organisations }\end{array}$ & 8 & 20 & 20 & 18 & 8 & 2.97 & $\mathrm{X}$ \\
\hline 6. & $\begin{array}{l}\text { RAWE has helped me to know } \\
\text { about the training programmes } \\
\text { organized at different agricultural } \\
\text { institutions and organisations for } \\
\text { transfer of technology }\end{array}$ & 21 & 23 & 15 & 13 & 2 & 3.64 & VI \\
\hline 7. & $\begin{array}{l}\text { RAWE has not helped me to } \\
\text { know about the agro climatic zone } \\
\text { wise location of agricultural } \\
\text { institutions in the different states }\end{array}$ & 7 & 19 & 15 & 25 & 8 & 3.10 & VIII \\
\hline 8. & $\begin{array}{l}\text { RAWE has not helped me to } \\
\text { know about the total geographical } \\
\text { area, rainfall, climate and soil of } \\
\text { each agro climatic zone of } \\
\text { different states visited }\end{array}$ & 9 & 24 & 18 & 16 & 7 & 2.87 & XI \\
\hline 9. & $\begin{array}{l}\text { RAWE has helped me to know } \\
\text { about the culture of different } \\
\text { states }\end{array}$ & 27 & 21 & 10 & 10 & 6 & 3.71 & V \\
\hline 10. & $\begin{array}{l}\text { RAWE has not helped me to } \\
\text { know about the historical places } \\
\text { of different states }\end{array}$ & 12 & 16 & 17 & 12 & 17 & 3.08 & IX \\
\hline 11. & $\begin{array}{l}\text { RAWE has helped me to develop } \\
\text { ability to live in a group }\end{array}$ & 39 & 21 & 11 & 1 & 2 & 4.27 & I \\
\hline 12. & $\begin{array}{l}\text { RAWE has helped me to live in } \\
\text { discipline }\end{array}$ & 31 & 20 & 10 & 11 & 2 & 3.90 & III \\
\hline
\end{tabular}

SA: Strongly agreed a: Agreed UD: Undecided

DA: Disagree SDA: Strongly Disagree 
The data further reveal that students have moderate attitude towards other statements of skill training in RAWE programme like "RAWE has developed capacity in me to start an enterprise", "RAWE has not helped me to develop leadership quality", "RAWE has not helped me to develop confidence and professional competence", and "RAWE has not helped me to develop ability of cooperation and team work" with score 3.47 , 3.30, 3.12 and 3.10 mean score respectively.

The reason being these aspects minimized the risk in startup of any enterprise. It reflects that skill training implemented for students bring significant improvement in students for development of the skill.

The students expressed least favourable attitude towards statements of skill training in RAWE programme like "RAWE has not helped me to develop favourable attitude about the related enterprise" and "RAWE has not helped me to improve the marketing skill" owing to the mean score 2.85 and 2.84 respectively. This might be due to the facts that most of students have better knowledge in entrepreneurship and marketing. This might be due to the reason that personal interest of students was in private sector. The findings of this study support the findings of $[2,5$,$] .$

\section{Attitude of students towards educational tour in RAWE programme}

The data given in table no. 3 indicate that students possessed most favourable attitude regarding "RAWE has helped me to develop ability to live in a group" which secured highest mean score (4.27 MS), hence this statement was ranked first. The second highest mean score (4.22 MS) secured by the statement "RAWE has helped me to know about the climate, soil, cropping system, land use pattern, irrigation sources and fertilizer status of different states" which was ranked second followed by "RAWE has helped me to live in discipline" (3.90 MS) and "RAWE has helped me to know about various technologies developed by different agricultural institutions of different states" (3.72 MS) ranked third and fourth, respectively.

Such results might be due to fact that educational tour is very important activity in SAUs which is helpful in exposure of the students with new institutions and technologies. Students were so cooperative in educational tour and spots visited very well under the guidance of good staff. This has resulted in to increased favourable attitude towards educational tour of RAWE programme.

The data given in table also reveal that students have moderate attitude towards other statements of educational tour in RAWE programme like "RAWE has helped me to know about the culture of different states", "RAWE has helped me to know about the training programmes organized at different agricultural institutions and organisations for transfer of technology", "RAWE has not helped me to know about the objectives and mandate of different agricultural institutions and organisations", "RAWE has not helped me to know about the agro climatic zone wise location of agricultural institutions in the different states" and "RAWE has not helped me to know about the historical places of different states" with score 3.71, 3.64, 3.18, 3.10 and 3.08 mean score respectively.

The students expressed least favourable attitude towards statements of educational tour in RAWE programme like "RAWE has not helped me to know about the working pattern of different agricultural institutions and organisations", "RAWE has not helped me to know about the total geographical area, 
rainfall, climate and soil of each agro climatic zone of different states visited" and "RAWE has not helped me to know about the livestock positions of different states" owing to the mean score $2.97,2.87$ and 2.85 respectively.

This might be due to the facts that education tour was implemented just reverse of these aspects. In educational tour total information was available regarding the area where educational tour conducted. This has resulted in least favourable attitude towards these statements in educational tour. The findings of this study support the findings of $[2,4$,$] .$

\section{References}

1. Report of fourth deans committee on Agricultural Education in India. Education Division, Indian Council of Agricultural Research New Delhi.3436.
2. Kumar, S. and Sharma, R.C. 2013. Outlook of Agriculture Undergraduates of JNKVV towards RAWE programme.TECHNOFAME-A Journal of Multidisciplinary Advance Research. 2 (1):40-43.

3. Badiger, C., Gavimath, U. and Ashalatha, K.V. 2003. Impact of Rural Home Science Work Experience Programme. Karnataka Journal of Agricultural sciences. 14(4):1001-1005.

4. Ayanwale, B.A. and Laagye, D.H. 2007. Perception of agriculture by students of tertiary institution in Nigeria. Agricultural Journal. 2(2):271-274.

5. Bordoloi, R., Borthakur, S. and Singh, A.K. 2013.Analysis of Utility Status of College Students in Assam Agricultural University under Rural Agricultural Work Experience Programme (RAWE). Journal of Human Ecology.42 (3):295302.

\section{How to cite this article:}

Kailash Chand Jakhar, Madhuri Joshi, Bajaranglal Choudhary and Sunil Kumar. 2017. Attitude of Students towards Rural Agriculture Work Experience Programme in Rajasthan State, India. Int.J.Curr.Microbiol.App.Sci. 6(7): 4429-4436. doi: https://doi.org/10.20546/ijcmas.2017.607.462 